\title{
Reminiscences of anti-racism training in the 1980s
}

Jackie Sayers

Jackie Sayers is an almost retired social worker who lives in Feilding. She worked for the Department of Social Welfare as both a basic grade and Senior social worker, the Palmerston North Hospital Board as a Student Unit Supervisor and Manawatu Polytechnic, where she taught social and community work. While in private practice she was a Competency Assessor for ANZASW for 13 years. She has been a member of ANZASW since 1980. She now does volunteer work for English Language Partners.

During the 1980s I enthusiastically embarked on study at master's level. My passion was anti-racism training for social work students. But work commitments, family, the complexity of the subject and life in general interceded and I failed in my commitment to complete my thesis despite having done most of the work. I felt I let the students down. Reflecting on this with colleagues recently, I was challenged to write something for the 50th anniversary journal publication of Social Work Review. These are my memories backed up with a little bit of checking in past publications of NZASW (New Zealand Association of Social Workers) as it was then known.

\section{Beginnings}

I had taken the trouble to get a book on New Zealand out of the local library in England before I set sail from Glasgow to New Zealand in 1958. I learnt about sheep and wheat and that the Queen had visited New Zealand in 1953. There were black and white photos of her being greeted by people called Maori who looked to me to be wearing grass skirts. I was intrigued because I had already spent several years nursing in the East End of London where I had experienced several diverse cultures. I arrived in New Zealand fully expecting to have to learn the local language in order to live here.

I had learnt a little more about New Zealand during my five-week journey on the ship. The 'Captain Cook' carried, during its lifetime, thousands of mainly British immigrants. Some were '10 Pound Poms' or, like me, married to a serviceman in the RNZAF (Royal New Zealand Air Force). My baby and I travelled for nothing. The ship provided panel talks about New Zealand so I learned that New Zealand had no racial problems and that there was no intermarriage between races (the term used at the time). I was also informed that it was a highly moral country and that women who misbehaved themselves on the ship would not be allowed to land.

So from my very first step into my new country I was interested in the people and history of New Zealand. What had I signed up for?

\section{Early experiences}

New Zealand, I found, was not quite as the panel of 'experts' on the Captain Cook led me to believe and during my early years in this country several incidents led me to see that prejudice was alive in well in 'God's Own'. 
As a family we moved around a great deal and one of these wanderings led us to a town where we were assigned a brand new house, along with three others in a small subdivision. A previously empty paddock, I guess, amongst established housing. We had the front house and there were three Maori families assigned the rest. I could not understand why the entire little subdivision was surrounded by a brand new six-feet high tin fence, except for our little bit on the street frontage. This was in the days of quarter-acre sections so there was a lot of fence. A brief chat to my neighbours explained that the neighbourhood had heard Maoris would be living in the houses, so up went the fence. It wasn't meant for me of course.

My experience in another New Zealand town was also enlightening. My daughter was to celebrate a teenage birthday with a party in the early 70s. She had invited a number of guests. I received a phone call from one mother asking if it was true that Maori boys would be at the party. I affirmed this. In which case, said the mum, 'my daughter is not allowed to come'. The high school debate topic around this time was 'Why aren't we allowed to go out with Maori boys?'

One more little story from another New Zealand town: I had a letter published in the local newspaper in the 1970s. I cannot remember the topic, but it obviously involved some Maori issue. I got an anonymous phone call calling me a 'nigger-loving bitch'.

My interest most definitely was piqued.

\section{Learning journey}

Eventually settling in the Manawatu allowed me to attend Massey University as an adult student, not the most common thing for older people in the early 1970s. Having been declined entry to primary teacher training, as I was considered to be too old and having too many children (36 and four respectively), I embarked on a course that included as many papers as possible relevant to New Zealand. I wanted to learn more about my adopted country and perhaps teach history at secondary level. A major in New Zealand history would have been nice but this was not available at undergraduate level in the 1970s - at least not at my local university. So to the few papers offered on New Zealand I was able to add some about the Pacific Islands, Australia and the Pacific side of Russia. At least they were around the area! One of these papers was on comparative race relations in Australia and New Zealand so I was introduced to the idea of 'race relations'. But most fortunately for me I was able to enrol in several papers taught by Maori academics headed by Hugh Kawharu. I would go from one tutorial run by the History department on the English language version of the Treaty of Waitangi to another run by the Maori department on the Maori version. This was an excellent example of 'talking past each other'.

\section{Social work and anti-racism}

This learning I was able to take into social work, a career I fell into because a degree in history was not desirous for secondary school teaching in the 1970s. Nobody seemed very interested in New Zealand history, and even less in anything Maori. In fact very little had been published about New Zealand social work either. The Hospitals Advisory Council 1972 , in a paper on improving social work training, failed to make any mention of racial issues and, in fact, did not acknowledge the existence of Maori at all. The New Zealand 
Social Work Training Council had no race relation goals in 1979. Of the four universities offering social work courses in 1978, only one offered a paper relating to Maori, to the best of my memory. This is not to say social work training did not include sensitivity training to other cultures, because I believe it did.

A visit to one of the Department of Social Welfare residences in the 1970s confirmed the lack of acknowledgment of Maori values and culture. My question as to the proportion of Maori at the residence was greeted with disdain as I was informed that such information was irrelevant as all the boys were treated the same. Incidentally, my other observation that there did not appear to be any women staff was answered with the retort that indeed there were women staff employed at the residence; ' they were in the kitchen where they belonged'.

But things were changing in New Zealand. The 1975 Land March brought to the public attention issues festering about Maori land alienation. I seem to remember the rallying cry 'Not one more acre'. A study of Maori land alienation post the signing of the Treaty of Waitangi is something I would recommend to all New Zealand social workers. I imagine that the widespread use of TV in most homes by that time was instrumental in bringing issues affecting Maori to Pakeha consciousness. TV also played a major role in the dissemination of information during the Springbok Tour of 1981.

The Springbok Tour of 1981 divided and rallied New Zealand around the causes of South Africa. Social workers around the country were heavily involved in the protests and I remember that in our city marches were held every Wednesday and Saturday throughout the entire period of the games - three months, I think. Staff from the Department of Social Welfare, including myself, marched around the city streets in their lunch breaks to be booed at by rugby supporters. A call had been made by the anti-tour movement for people to wear black armbands, as if in mourning. So I wore one to work, only to be hauled before the boss for inappropriate dress for a government employee. Fair enough. I subsequently dressed entirely in black for the remainder of the tour. Not much of a protest, but it was the best I could do at the time.

However, when the issues of racism were discussed at local anti-racist meetings, many people did not make the connection between racism elsewhere and racism in our own backyard. There was almost total denial by many of the general public of racial issues in New Zealand. We were 'all one people'.

\section{Social workers in action}

Social workers were at work around the country addressing the issues, however. This was the time of structural analysis for understanding and guiding our practice. Workshops were organised - some run by social work trainers financed by the state, if I remember correctly. There were also anti-racism workshops run by groups, one I recall named 'The Urban Group to Combat Racism' and another 'New Perspectives on Race'. Social workers were able to attend workshops as part of their in-service training.

The New Zealand Association of Social Workers set up a working party in 1983 to highlight racism in social work. The social workers at the hospital I then worked at set up G.A.R.P. - Group Against Racist Practices, and we monitored and ran workshops within the 
hospital. The Department of Social Welfare produced the Women Against Racism Action Group (WARAG) Report which, if I remember correctly, was written by nine women workers employed by the Department. The report was critical of the Department.

The NZASW working party on racism published Race Against Time in 1984 and Josephine Serrallach, a social worker with the Department of Social Welfare, addressed the Social Workers World Conference in Stockholm in 1988 on 'Social Work \& White Racism'. This was about New Zealand.

Puao-Te-Ata-Tu was published in 1988. As I still have a copy, I can write that it was charged by the Minister of Social Welfare at the time to investigate and report from a Maori perspective on the activities of the Department of Social Welfare. The committee identified a number of problem areas. Recommendations included attacking all forms of cultural racism in New Zealand that had resulted in the values and lifestyle of the dominant group being regarded as superior to those of other groups, especially Maori. Recommendations were also made for training those working in the social services. This report, Puao-Te-Ata-Tu, became the 'bible' of the Department of Social Welfare. It was instrumental in the rewriting of child welfare legislation.

\section{The research}

During the 1980s the anti-racism workshops I was involved in were held both in the community, and within the formal training programme for social work students at Massey University. It was the way people were being challenged about racism at these workshops which caused unease for me. It was this unease that led to my research.

At one anti-racism workshop I attended as a participant, not a trainer, I was challenged, along with others, to the point of being told one should not be in New Zealand but should return to one's own country. Immigrants had no right to be here. What had happened to Maori was 'our fault'. Workshop participants were left feeling guilty, or they were meant to feel guilty. Some were left feeling angry. As a social worker, this kind of approach did not fit with my belief that all people are valued and that one works with people, not blaming them, being non-judgemental, being respectful. My attempt to discuss my unease with one trainer was met with the response that I was the one with the problem and that what I needed was more anti-racism training. As this confrontational approach was the perceived wisdom of the time, this was the method used to some extent by myself, and my colleagues.

For my research on social work students, I was able to survey a class of first-year students about the workshop they were currently engaged in and also survey retrospectively fourth years about their experience. It was pretty obvious that for the young, mostly female, first-year students the experience of the type of workshop they received was often negative. Very thought provoking for me as I was one of the presenters. The fourth years had much longer to process the experience, but their suggestions for future training were enlightening and helpful.

The fourth years wanted to know more about the Treaty of Waitangi. They wanted to know more about Maori culture and values. They wanted to know more about a lot of 
things historical - land alienation being one of them. In fact, they wanted education and they wanted to learn.

At some stage, methods of presentation began to change and groups like Project Waitangi took a more educational approach. I'm unsure when Project Waitangi started up, but I believe this group was instrumental in disseminating much of the knowledge social workers wanted to know.

So I am sorry I did not complete the study of those students' experience of anti-racism training and finish my thesis, but life intervened. I still learnt from their experiences, however.

I remain forever grateful to the students for sharing their experiences with me and for guiding me towards the theories and practices of adult education. They helped me learn how to teach. Now that's another story!

\section{References}

Berridge, D., Cowan, L., Cumberland, T., Davys, A., McDowell, H., Morgan, J., \& Wallis, P. (1984). Institutional racism in the Department of Social Welfare Auckland. Auckland: Department of Social Welfare.

Hospitals Advisory Council. (1972). Report of committee on means of improving training for social workers entering the Health Services. Wellington: Hospitals Advisory Council.

Ministerial Advisory Committee on a Maori Perspective for the Department of Social Welfare (September 1988). Puao-Te-Ata-Tu. Wellington.

New Zealand Committee on Means of Improving Training for Social Workers Entering the Health Services. (1972). New Zealand Hospitals Advisory Council.

NZASW Working Party on Racism. (1984). Race against time. New Zealand Social Work, 9(2).

de Serrallach, J. B. (1988). Social work and white racism. Social Work Review, 1(2).

Tauroa, H. (1982). Race against time. Human Rights Commission: Wellington. 